\title{
PERLINDUNGAN HUKUM SAKSI DAN KORBAN OLEH LEMBAGA PERLINDUNGAN SAKSI DAN KORBAN (LPSK)
}

\author{
Oleh : Mamay Komariah, S.H., M.H. *)
}

\begin{abstract}
ABSTRAK
Undang-Undang No. 13 Tahun 2006 tentang Perlindungan Saksi dan Korban dibentuk untuk memberikan rasa aman terhadap setiap saksi dan/atau korban dalam memberikan keterangan pada setiap proses peradilan pidana. Penulisan tentang "Perlindungan Hukum Saksi dan Korban Oleh Lembaga Perlindungan Saksi dan Korban" ini bertujuan untuk memberikan penjelasan secara lebih jelas tentang mekanisme dan kinerja LPSK dalam menjalankan tugas dan wewenangnya. Perlindungan dalam UU No. 13 Tahun 2006 diartikan sebagai segala upaya pemenuhan hak dan pemberian bantuan untuk memberikan rasa aman kepada saksi dan/atau korban yang wajib dilaksanakan oleh LPSK atau lembaga lainnya sesuai dengan ketentuan Undang-Undang ini.

Mekanisme pemberian perlindungan terhadap saksi dan korban diatur dalam pasal 28-32 UU No. 13 Tahun 2006 yang mencakup berbagai prosedur dan persayaratan yang harus dipenuhi oleh saksi dan/atau korban untuk bisa mendapatkan perlindungan dari LPSK yang terkadang sulit dilakukan oleh saksi dan/atau korban tersebut. Kinerja LPSK dalam menjalankan tugasnya pun dipandang kurang efektif. Kelemahan Undang-undang Perlindungan Saksi dan Korban yaitu, saksi dan/atau korban haruslah mengajukan permohonan kepada LPSK agar mereka bisa mendapatkan perlindungan dari LPSK, disamping mereka juga harus memenuhi persyaratan yang telah ditentukan oleh LPSK. kurangnya informasi bagi masyarakat, sehingga minimnya pengetahuan masyarakat akan kehadiran LPSK ini walaupun telah diundangkannya UU Perlindungan Saksi dan Korban.

Kata Kunci : Perlindungan, Saksi dan Korban
\end{abstract}

\section{ABSTRACT}

Law No. 13 of 2006 on the Protection of Witnesses and Victims was established to provide security to every witness and / or victim to testify in any criminal proceedings. Writing on "Legal Protection of Witnesses and Victims Protection Agency by the Witness and Victim" is intended to provide a clearer explanation of the mechanisms and the performance of the Agency in carrying out its duties and authorities. Protection in Law 13 of 2006 is defined as all efforts to fulfill the rights and the provision of assistance to provide security to witnesses and / or victims which must be implemented by the Agency or other agencies in accordance with the provisions of this Act.

Mechanisms for providing protection to witnesses and victims set forth in article 28-32 of Law No. 13 of 2006 which includes a variety of procedures and the requirement to be met by witnesses and / or victims to get protection from the Agency that is sometimes difficult for the witnesses and / or victims. Agency's performance in carrying out its duties are regarded as less effective. Weakness Act Witness and Victim Protection, namely, witnesses and / or victims must submit an application to the Agency so that they can get protection from the Agency, in addition they must also meet the requirements set by the Agency. lack of information for the public, so that the lack of public knowledge of the Agency's presence even after the enactment of the Witness and Victim Protection Act.

Keywords: Protection, the Witness and Victim.

*) Staf Pengajar Fakultas Hukum Universitas Galuh 


\section{PENDAHULUAN}

\section{A. Latar Belakang Masalah}

Negara Indonesia sebagai negara hukum perlu memahami dengan keadaan dunia yang telah mulai banyak memperhatikan Hak Asasi Manusia, sehingga di era reformasi sebuah agenda besar tersebut menuntut adanya perubahan sebuah tata kehidupan dalam berbangsa dan bernegara. Salah satu dari perubahan tersebut yang menonjol adalah mengenai perlindungan hak-hak warga negara yang berkaitan dengan

Hak Asasi Manusia itu sendiri. Dalam perlindungan Hak Asasi Manusia telah banyak perlindungan yang telah dengan jelas dan tegas diatur dalam sebuah peraturan perundang-undangan seperti yang telah diatur dalam undangundang perlindungan anak, perlindungan perempuan, kekerasan dalam rumah tangga dan lain sebagainya yang selanjutnya baru kemudian perlindungan saksi hampir terlupakan dalam agenda reformasi.

Perlindungan hukum merupakan suatu bentuk pelayanan yang wajib diberikan oleh pemerintah untuk memberikan rasa aman kepada setiap warga masyarakat. Berdasarkan Undang-undang Dasar Negara Republik Indonesia Tahun 1945 bahwa Negara bertanggung jawab atas perlindungan
Hak Asasi Manusia merupakan suatu hal yang sangat penting, seperti diuraikan dalam Pasal 28I ayat (4) Undang-undang Dasar Negara Republik Indonesia Tahun 1945 yang berbunyi : "Perlindungan, pemajuan, penegakan, dan pemenuhan hak asasi manusia adalah tanggung jawab negara, terutama pemerintah".

Perlindungan bagi warga negara terhadap tindakan pemerintah. Menurut Phipus M. Hadjon, perlindungan hukum itu ada dua yaitu : "Perlindungan hukum preventif dan represif. Pada perlindungan hukum preventif diberikan kesempatan untuk mengajukan keberatan (inspraak) atau pendapat sebelum suatu keputusan pemerintah mendapat bentuk yang definitive. Artinya perlindungan hukum yang preventif bertujuan untuk mencegah terjadinya sengketa, sedangkan sebaliknya perlindungan hukum preventif sangat signifikan bagi tindak pemerintah yang didasarkan pada kebebasan bertindak, karena dengan adanya perlindungan hukum yang preventif Pemerintah terdorong untuk bersikap hati-hati dalam mengambil keputusan yang didasarkan pada diskresi". (Phipus, Hadjon; 1987 : 2).

Hukum pidana adalah hukum sanksi, sebab dengan bertumpu pada sanksi itulah hukum pidana difungsikan 
untuk menjamin keamanan, ketertiban, dan keadilan, akan tetapi dalam penyelesaian perkara pidana, sering kali hukum terlalu mengedepankan hak-hak tersangka/terdakwa, sementara hak-hak korban diabaikan. Fungsi dari Hukum Pidana berkaitan dengan fungsi hukum pada umumnya merupakan bagian dari hukum pada umumnya yaitu untuk mengatur hidup kemasyarakatan atau menyelenggarakan tata tertib dalam masyarakat, yang bertujuan untuk menegakkan tertib hukum, melindungi masyarakat hukum manusia serta memberikan rasa takut untuk melakukan perbuatan pidana dan mendidik orang yang melakukan perbuatan pidana supaya sadar sehingga menjadi orang yang lebih baik lagi. (Sudikno, Mertokusumo; 1993 : 145).

Lingkup perlindungan oleh LPSK adalah pada semua tahap proses peradilan pidana, agar saksi dan/atau korban merasa aman ketika memberikan keterangan atau kesaksian. Peranan saksi dan korban dalam setiap persidangan perkara pidana sangat penting karena kerap keterangan saksi dan korban dapat mempengaruhi dan menentukan kecendrungan putusan hakim.

Jantungnya suatu proses peradilan adalah dalam tahap pembuktian. Dalam tahap pembuktian di persidangan akan di hadapkan dengan berbagai alat bukti yang dihadirkan sesuai dengan keterkaitan dengan tindak pidana yang sedang di gelar. Salah satu alat bukti yang sah dalam proses peradilan pidana adalah keterangan saksi dan/atau korban yang mendengar, melihat, atau mengalami sendiri terjadinya suatu tindak pidana dalam upaya mencari dan menemukan kejelasan tentang tindak pidana yang dilakukan oleh pelaku tindak pidana. Dalam proses pengungkapan suatu proses pidana mulai dari tahap penyidikan sampai dengan tahap pembuktian persidangan keberadaan keberadaan dan peran sanksi sangatlah di harapkan. Bahkan menjadi faktor penentu dan keberhasilan dalam pengungkapan kasus pidana yang dimaksud.

Pentingnya perlindungan hukum terhadap setiap anggota masyarakat yang menjadi salah satu alasan dibuat Undang-undang Nomor 13 Tahun 2006 tentang Perlindungan Saksi dan Korban. Dalam Undang-undang ini, diatur pula tentang sebuah lembaga yang bertanggung jawab untuk menangani pemberian perlindungan dan bantuan pada saksi dan korban yaitu Lembaga Perlindungan Saksi dan Korban (LPSK) yang bertugas dan berwenang untuk memberikan perlindungan dan bantuan kepada saksi dan korban. 
Kedudukan saksi dalam proses peradilan pidana menempati posisikunci, sebagaimana terlihat dalam Pasal 184 Kitab Undang-undangHukum Acara Pidana. Jadi jelas bahwa saksi mempunyai kontribusi yang sangatbesar dalam upaya menegakkan hukum dan keadilan.Berhubungan dengan hal tersebut, saksi merupakan salah satufaktor penting dalam pembuktian atau pengungkapan fakta yang akandijadikan acuan dalam menemukan bukti-bukti lain untuk menguatkansebuah penyelidikan, penyidikan, dan bahkan pembuktian di pengadilan. (Sudikno, Mertokusumo; 1993 : 145)

Persoalan yang kadang dijumpai dalam proses peradilan pidana adalah banyaknya saksi yang tidak bersedia menjadi saksi ataupun tidak berani mengungkapkan kesaksian yang sebenarnya karena tidak adanya jaminan yang memadai atas perlindungan maupun mekanisme tertentu untuk bersaksi. Saksi termasuk pelapor bahkan sering mengalami intimidasi ataupun tuntutan hukum atas kesaksian atau laporan yang diberikannya.

Dalam kenyataannya tugas dan kewenangan LPSK dalam Undangundang Perlindungan Saksi dan Korban tidak diatur secara spesifik. Undang- undang Perlindungan Saksi dan Korban hanya mengatur mengenai tanggung jawab LPSK, keanggotaan dan proses seleksi LPSK, dan pengambilan keputusan dan pendanaan namun tidak mengatur secara spesifik mengenai organisasi dan dukungan kelembagaan, administrasi, SDM, pengawasan, serta tranparansi dan akuntabilitas dari LPSK.

Dengan demikian, maka jelas bahwa ketersediaan mekanisme perlindungan saksi dan korban amat penting untuk menjamin diperolehnya kebenaran materil sekaligus untuk memenuhi rasa keadilan bagi semua, termasuk bagi saksi dan korban yang terkait.Berdasarkan latar belakang yang telah di paparkan di atas maka penulis memilih judul : "Perlindungan Hukum Saksi dan Korban oleh Lembaga Perlindungan Saksi dan Korban (LPSK)".

\section{B. Perumusan Masalah}

a. Bagaimanakah mekanisme perlindungan hukum oleh LPSK berdasarkan Undang-Undang Nomor 13 Tahun 2006 tentang Perlindungan Saksi dan Korban?

b. Bagaimanakah efektivitas pemberian perlindungan hukum kepada saksi dan korban oleh LPSK ?

c. Bagaimanakah hambatan atau kendala-kendala dalam Undang- 
Undang Nomor 13 Tahun 2006 tentang Perlindungan Saksi dan Korban?

\section{Tujuan penelitian}

a. Untuk mengetahui mekanisme perlindungan hukum terhadap saksi dan/atau korban oleh Lembaga Perlindungan Saksi dan Korban (LPSK) berdasarkan Undang-undang Nomor 13 Tahun 2006 tentang Perlindungan Saksi dan Korban.

b. Untuk mengetahui efektivitas pemberian perlindungan hukum kepada saksi dan korban oleh LPSK?

C. Untuk mengetahui hambatan atau kendala-kendala dalam UndangUndang Nomor 13 Tahun 2006 tentang Perlindungan Saksi dan Korban.

\section{Manfaat penelitian}

a. Secara teoritis penelitian ini diharapkan dapat memberikan sumbangan ilmiah bagi ilmu pengetahuan hukum dalam pengembangan hukum pidana.

b. Secara Praktis hasil penelitian yang berfokus pada perlindungan hukum ini diharapkan bisa menjadi bahan pertimbangan dan sumbangan pemikiran serta dapat memberikan kontribusi dan solusi konkrit bagi para legislator dalam upaya memberikan perlindungan hukum terhadap saksi dan korban tindak pidana di Indonesia.

\section{TINJAUAN PUSTAKA}

\section{A. Pengertian Perlindungan Hukum}

Perlindungan hukum merupakan suatu bentuk pelayanan yang wajib diberikan oleh pemerintah untuk memberikan rasa aman kepada setiap warga masyarakat. Berdasarkan Undang-undang Dasar Negara Republik Indonesia Tahun 1945 bahwa Negara bertanggung jawab atas perlindungan Hak Asasi Manusia merupakan suatu hal yang sangat penting, seperti diuraikan dalam Pasal 28I ayat (4) Undang-undang Dasar Negara Republik Indonesia Tahun 1945 yang berbunyi:“Perlindungan, pemajuan, penegakan, dan pemenuhan hak asasi manusia adalah tanggung jawab negara, terutama pemerintah".

Perlindungan merupakan suatu aspek yang penting yang harus dimiliki oleh setiap warga masyarakat. Dalam Pasal 1 butir 6 Undang-Undang No. 13 Tahun 2006 tentang Perlindungan Saksi dan Korban menyebutkan bahwa Perlindungan adalah segala upaya pemenuhan hak dan pemberian bantuan untuk memberikan rasa aman kepada Saksi dan/atau Korban yang wajib 
dilaksanakan oleh LPSK atau lembaga lainnya sesuai dengan ketentuan Undang-Undang ini.

Perlindungan yang diberikan pada korban atau saksi dapat diberikan pada tahap penyelidikan, penyidikan, penuntutan, dan atau pemeriksaan di sidang pengadilan, atas dasar inisiatif dari aparat penegak hukum, aparat keamanan, dan atau dari permohonan yang disampaikan oleh korban.Dengan adanya perlindungan hukum dari LPSK, penjaminan atas rasa aman terhadap saksi dan korban pun menjadi semakin kuat. Perlindungan hukum terhadap saksi dan korban selama ini didasarkan pada KUHP sebagai sumber hukum materiil, dengan menggunakan KUHAP sebagai hukum acara. Akan tetapi di dalam KUHAP lebih banyak diatur tentang tersangka dari pada mengenai saksi dan korban. Kedudukan saksi dan korban pun tampaknya belum optimal dibandingkan kedudukan pelaku.

Bentuk perlindungan hukum lain yang dapat diberikan kepada korban adalah melalui pemberian kompensasi, retribusi, dan rehabilitasi sebagaimana yang diatur dalam Peraturan Pemerintah Nomor 44 Tahun 2008 tentang Pemberian Kompensasi, Retribusi, Dan Bantuan Kepada Saksi dan Korban.

Dalam rangka pengaturan dan perlindungan saksi dan korban di
Indonesiamelalui perundang-undangan tersendiri dengan melihat praktek selama ini sepertikiranya perluperlindungan saksi dan korban diatur dalam undang-undang tersendiri. Namun halyang perlu diperhatikan adalah memberikan definisi yuridis dari "Saksi atauKorban", sehingga dapat ditentukan batas-batas pengaturannya. Untukmemudahkan kiranya dapat diambil dari Pasal 1 angka 26 yang menentukan"Saksi adalah orang yang dapat memberikan keterangan guna kepentinganpenyidikan, penuntutan, dan peradilan tentang suatu perkara pidana yang iadengar sendiri, ia lihat sendiri, dan ia alami sendiri dengan menyebut alasan daripengetahuan itu".

Sedangkan untuk korban dapat didefinisikan: "a victim is aperson who has suffered damage as a result of a crime and or whose sense ofjustice has been directly disturb by the experience of having been the target of acrime", artinya korban adalah seseorang yang telah menderita kerugian sebagaiakibat suatu kejahatan dan/atau rasa keadilannya secara langsung telah terganggusebagai akibat pengalamannya sebagai sasaran kejahatan.

Kitab Undang-undang Hukum Acara Pidana Pasal 1 butir 26menyatakan bahwa "Saksi adalah 
orang yang dapat memberikan keterangan guna kepentingan penyidikan, penuntutan, dan peradilan tentang suatu perkara pidana yang didengar sendiri, ia lihat sendiri dan iaalami sendiri.

Pasal 1 butir 27 Kitab Undangundang Hukum Acara Pidana jugamemberikan penjelasan bahwa "Keterangan saksi adalah salah satu alatbukti dalam perkara pidana yang berupa keterangan dari saksi mengenaisuatu peristiwa pidana yang ia dengar sendiri, ia lihat sendiri dan ia alamisendiri dengan menyebut alasan dari pengetahuan

itu".

Subektimenyatakan bahwa saksi adalah orang yang didengar keterangannya dimuka sidang pengadilan, yang mendapat tugas membantu pengadilanyang sedang perkara.

Uraian di atas penunjukkan bahwa saksi dalam proses peradilanadalah faktor penting dalam setiap tahap dalam proses peradilan pidana.Suryono Sutarto lebih luas mengemukakan bahwa saksi adalah orangyang memberikan keterangan guna kepentingan penyidikan, penuntutan,dan peradilan tentang suatu perkara pidana yang ia dengar sendiri, ia lihatsendiri dan ia alami sendiri.Selanjutnya Pasal 166 Kitab Undang-undang Hukum Acara
Pidanamenyatakan bahwa pertanyaan yang bersifat "sugestif"/menjerat tidak boleh dilakukan terhadap saksi atau terdakwa.

Wirjono Projodikoro memaknai bahwa Seorang saksi adalahseorang manusia belaka atau manusia biasa. la dapat dengan sengajabohong, dan dapat juga jujur menceritakan hal sesuatu, seoalah-olah halyang benar, akan sebetulnya tidak benar. Seseorang saksi harusmenceritakan hal yang sudah lampau, dan tergantung dari daya ingat dariorang perseorang, apa itu dapat dipercaya atas kebenarannya. (Wirjono, Projodikoro; 1981 : 156).

Perlindungan adalah segala upaya pemenuhan hak dan pemberianbantuan untuk memberikan rasa aman kepada saksi dan/atau korbanyang wajib dilaksanakan oleh Lembaga Perlindungan Saksi dan Korbanatau lembaga lainnya sesuai dengan ketentuan Undang-undang ini.Perlindungan saksi dan korban bertujuan memberikan rasa aman kepadaSaksi dan/atau Korban dalam memberikan keterangan pada setiap prosesperadilan pidana.

\section{B. Konsep dan Dasar Perlindungan Saksi dan Korban \\ Pada awalnya keberadaan saksi dan korban kuranglah diperhitungkan.}


Keselamatan baik untuk dirinya sendiri maupun keluarga pada kasus-kasus tertentu menjadi taruhannya atas kesaksian yang mereka berikan. Dalam KUHAP cenderung lebih memberatkan pemberian perlindungan kepada warga negara yang berstatus tersangka, terdakwa dan terpidana.

Pada tahun 2006 pemerintah mengeluarkan peraturan perundangundangan berupa Undang-Undang Nomor 13 Tahun 2006 tentang Perlindungan Saksi dan Korban yang di undangkan pada 11 Agustus 2006. Peranan saksi dan juga korban sangatlah penting dalam rangka untuk melahirkan sebuah keputusan yang adil dan obyektif. Untuk itulah perlindungan terhadap saksi dan korban menjadi sangat penting juga.

Menurut Muladi menyatakan bahwa perlunya pengaturan danperlindungan hukum bagi saksi dan korban dapat dibenarkan secarasosiologis bahwa dalam kehidupan bermasyarakat semua warga negaraharus berpartisipasi penuh, sebab masyarakat dipandang sebagai systemkepercayaan yang melembaga "system of in instuitutionalizet trust".Tanpakepercayaan ini, kehidupan sosial tidak mungkin berjalan baik, sebab tidakada pedoman atau patokan yang pasti dalam bertingkah
laku.Kepercayaan ini terpadu melalui norma-norma yang diekspresikan didalam struktur kelembagaan (organisasi) seperti kepolisian, kejaksaan,pengadilan, lembaga koreksi dan sebagainya.

Muladi selanjutnya menyatakan bahwa dalam rangka pengaturanhukum pidana terhadap korban kejahatan, secara mendasar dikenal adadua model, yakni

(a) model hak-hak prosedural (the Procedural RightsModel);

(b) model pelayanan (the Services Model).

\section{PEMBAHASAN}

Mekanisme perlindungan hukum terhadap saksi dan korban oleh Lembaga Perlindungan Saksi dan Korban (LPSK) berdasarkan UndangUndang Nomor 13 Tahun 2006 tentang Perlindungan Saksi dan Korban Hadirnya Undang-undang Nomor 13 tahun 2006 tentang Perlindungan Saksi dan Korban memberikan harapan bahwa kesaksian yang diberikan berlandaskan rasa aman dan nyaman. Perlindungan terhadap saksi dan korban diberikan berdasarkan beberapa asas seperti yang tercantum dalam Pasal 3 Undang-Undang Nomor 13 Tahun 2006 yaitu : 
1. Penghargaan atas harkat dan martabat

2. Rasa aman

3. Keadilan

4. Tidak diskriminatif, dan

5. Kepastian hukum

Sebelum saksi dan korban agar bisa mendapatkan perlindungan hukum dari Lembaga Perlindungan Saksi dan Korban (LPSK), mereka harus melewati beberapa prosedur yang telah ditetapkan oleh Lembaga Perlindungan Saksi dan Korban (LPSK) disamping mereka harus memenuhi persyaratan untuk mendapat perlindungan dari Lembaga Perlindungan Saksi dan Korban (LPSK) ini seperti yang telah dijelaskan dalam Pasal 28, Pasal 29, Pasal 30, Pasal 31, Pasal 32, Pasal 33, Pasal 34, Pasal 35 dan Pasal 36 Undang-Undang Nomor 13 Tahun 2006 tentang Perlindungan Saksi dan Korban.

Pasal 28 Undang-undang Nomor 13 Tahun 2006 tentang Perlindungan Saksi dan Korban memberikan penjelasan bahwa setiap saksi dan/atau korban bisa menerima perlindungan hukum dari Lembaga Perlindungan Saksi dan Korban (LPSK) jika memenuhi syarat-syarat yang telah dijelaskan dalam pasal tersebut. Selain itu juga harus memenuhi persyaratan formil dan materil yang telah diatur dalam ketentuan Pasal 5 peraturan Lembaga Perlindungan Saksi dan Korban Nomor 6 Tahun 2010 tentang tata cara pemberian perlindungan saksi dan korban.

Mengenai penjelasan sebagaimana dimaksud dalam Pasal 5 tersebut diatur dalam ketentuan Pasal 6 Peraturan LPSK. Tata cara pemberian Perlindungan terhadap saksi dan korban dipaparkan dalam Pasal 29 Undangundang Nomor 13 Tahun 2006 tentang Perlindungan Saksi dan Korban yang berbunyi sebagai berikut : "Tata cara memperoleh perlindungan sebagaimana dimaksud dalam Pasal 5 sebagai berikut :

a. Saksi dan/atau Korban yang bersangkutan, baik atas inisiatif sendiri maupun atas permintaan pejabat yang berwenang, mengajukan permohonan secara tertulis kepada LPSK;

b. LPSK segera melakukan pemeriksaan terhadap permohonan sebagaimana dimaksud pada huruf a;

c. Keputusan LPSK diberikan secara tertulis paling lambat 7 (tujuh) hari sejak permohonan perlindungan diajukan."

Dari ketentuan Pasal 29 ini ada pengaturan mengenai apakah permohonan itu secara tertulis atau permohonan perlindungan seharusnya bukan cuma dari pihak saksi/korban dan 
pejabat yang berwenang tetapi juga oleh keluarga saksi dan korban yang bersangkutan dan pendamping saksi dan korban.

Penjelasan terhadap tata cara pemberian perlindungan sebagaimana dimaksud yang menjadi kewajiban bagi Lembaga Perlindungan Saksi dan Korban juga terdapat dalam ketentuan Pasal 30 dan pada Pasal 31, Pasal 29 Undang-undang Nomor 13 Tahun 2006 tentang Perlindungan Saksi dan Korban yang menyebutkan sebagai berikut :

Pasal 30 ayat (1) Dalam hal LPSK menerima permohonan Saksi dan/atau Korban sebagaimana dimaksud dalam Pasal 29, Saksi dan/atau Korban menandatangani pernyataan kesediaan mengikuti syarat dan ketentuan perlindungan Saksi dan Korban.

Ayat (2) Pernyataan kesediaan mengikuti syarat dan ketentuan perlindungan Saksi dan Korban sebagaimana dimaksud pada ayat (1) memuat :

a. Kesediaan Saksi dan/atau Korban untuk memberikan kesaksian dalam proses peradilan;

b. Kesediaan Saksi dan/atau Korban untuk mentaati aturan yang berkenaan dengan keselamatannya;

c. Kesedian Saksi dan/atau Korban untuk tidak berhubungan dengan cara apa pun dengan orang lain selain atas persetujuan LPSK, selama ia berada dalam perlindungan LPSK;

d. Kewajiban Saksi dan/atau Korban untuk tidak memberitahukan kepada siapa pun mengenai keberadaannya di bawah perlindungan LPSK; dan

e. Hal-hal lain yang dianggap perlu oleh LPSK.

Proses pengajuan permohonan hingga disetujuinya permohonan tersebut sering kali membingungkan para saksi dan korban, karena mereka harus melewati proses yang tidak pendek untuk mendapat perlindungan dari LPSK ini. Hal inilah yang sering menjadi penyebab saksi dan atau korban merasa enggan untuk meminta perlindungan dari LPSK dan memilih untuk diam. Para saksi dan korban merasa kurang mengerti akan prosedurprosedur yang ditetapkan oleh LPSK. Apalagi bagi para saksi dan korban yang tidak begitu mengerti akan hukum. Karena itulah pemdampingan akan seorang advokat sangat membantu para saksi dan korban ini.

Tata cara pemberian bantuan kepada saksi atas permintaan tertulis, dari yang bersangkutan atau orang yang mewakilinya kepada Lembaga Perlindungan Saksi dan Korban, adapun tata cara pemberian bantuan kepada 
saksi oleh Lembaga Perlindungan Saksi dan Korban adalah sebagai berikut :

1. Lembaga Perlindungan Saksi dan Korban menentukan kelayakan diberikannya bantuan kepada saksi

2. Dalam hal saksi layak diberikan bantuan, Lembaga Perlindungan Saksi dan Korban menentukan jangka waktu dan besaran biaya yang diperlukan Keputusan LembagaPerlindungan Saksi dan Korban mengenai pemberian bantuan akan diberitahukan secara tertulis kepada yang bersangkutan dalam jangka waktu 1 minggu.

Lembaga Perlindungan Saksi dan Korban bisa bekerja sama dengan instansi berwenang terkait dalam pemberian perlindungan dan bantuan, instansi terkait wajib melaksanakan keputusan Lembaga Perlindungan Saksi dan Korban sesuai dengan ketentuan yang diatur dalam Undang-Undang.

Saksi dan/korban yang berada dibawah perlindungan LPSK, tidaklah secara sepenuhnya merasa aman, karena banyaknya persoalan yang kian datang sesuai dengan berjalannya suatu persidangan. Dalam setiap tahap pemeriksaan mulai dari tingkat penyidikan sampai pemeriksaan di pengadilan yang memakan waktu cukup lama. Bebearapa perkara yang telah berlangsung cukup lama, sehingga saksi atau korban lupa akan peristiwa itu, tetapi di depan sidang pengadilan harus dituntut kebenaran kesaksiannya. Dalam fase yang seperti ini kehadiran LPSK sangat diperlukan. Karena kehadiran LPSK diharapkan dapat memberikan rasa nyaman dan aman bagi saksi atau korban agar dapat memberikan kesaksian di depan persidangan dan proses persidangan dapat berjalan tanpa berbelit-belit.

Lembaga Perlindungan Saksi dan Korban (LPSK) berdiri berdasarkan Undang-Undang Nomor 13 Tahun 2006 tentang Perlindungan Saksi dan Korban. LPSK merupakan suatu lembaga yang di bentuk untuk menangani pemberian perlindungan dan bantuan pada saksi dan korban berdasarkan tugas dan wewenang sebagaimana diatur dalam Undang-Undang Perlindungan Saksi dan Korban.

Perlindungan hukum terhadap saksi dan korban selama ini didasarkan pada KUHP sebagai sumber hukum materiil, dengan menggunaka KUHAP sebagai hukum acara. Dalam KUHAP lebih banyak diatur tentang tersangka dari pada mengenai saksi dan korban.

Implementasi dari ide keseimbangan di atas yang berkaitandengan perlindungan saksi adalah implementasi pada ide keseimbangan yang berorientasi pidana 
pada perlindungan masyarakat, korban danpelaku, yang tidak terlepas dengan perlindugan Hak Asasi Manusia. (Barda Nawawi Arief, 2006).

Dengan ide dasar keseimbangan ini Hak Asasi Manusia sangat penting, terlebih dalam proses peradilan pidana seorang saksi yang merupakan kunci dalam menemukan titik terang sebuah tindak pidana. Oleh karenaitu dalam proses peradilan pidana harus dilindungi karena itu merupakanhak asasi yang paling mendasar yang dimiliki setiap manusia termasuksaksi. (Barda Nawawi Arief, 2006).

Saksi merupakan faktor penting dalam perkara pidana terutama dalam hal menemukan terangnya sebuah tindak pidana, sehingga tidak dibenarkan pula dalam melakukan pemeriksaan pihak pemeriksa mengadakan tekanan yang bagaimanapun caranya misalnya pada kasus ancaman, dan sebagainya yang dapat menyebabkan terdakwa atau saksi menerangkan hal berlainan yang dianggap tidak sebagai pernyataan pikiran bebas.

Kedudukan saksi dan korban pun tampaknya belum optimal dibandingkan kedudukan pelaku. Walaupun telah diundangkannya Undang-Undang Nomor 13 Tahun 2006 tentang Perlindungan Saksi dan Korban, akan tetapi pemberian perlindungan terhadap saksi dan korban ini dipandang masih belum maksimal. Undang-Undang Perlindungan Saksi dan Korban dinilai belum cukup untuk menjamin perlindungan saksi dan korban yang secara langsung memperhambat kinerja dari LPSK sendiri. Salah satunya yaitu: UU Perlindungan Saksi dan Korban ini belum secara khusus mengatur mengenai wewenang seperti apakah yang dimiliki oleh LPSK dalam rangka pemberian perlindungan terhadap saksi dan korban, yang terkadang menyebabkan LPSK sering salah jalan dalam melakukan tugasnya.

Perlunya pengaturan dan perlindungan hukum bagi saksi korbandapat dibenarkan secara sosiologis bahwa dalam kehidupanbermasyarakat semua warga negara harus berpartisipasi penuh, sebabmasyarakat dipandang sebagai sistem kepercayaan yang melembaga ("system of instituitionalized trust"). Tanpa kepercayaan ini makakehidupan sosial tidak mungkin berjalan dengan baik sebab tidak adapatokan yang pasti dalam bertingkah laku. Kepercayaan ini terpadu melalui norma-norma yang diekspresikan di dalam struktur organisasional seperti polisi, jaksa, pengadilan dan sebagainya. 
Menurut Mula didalam rangka konsep pengaturan terhadap korbankejahatan, maka pertama-tama yang harus diperhatikan adalah esensi kerugian yang diderita korban. (Muladi, 2002 : 175-176). Ternyata esensi kerugian tersebut tidak hanya bersifat material atau penderitaan fisik saja, melainkan juga bersifat psikologis. Jika diperhatikan dan dikaitkan denganmandat dari undang-undang tugas maupun kewenangan yang diberikan oleh Undang-Undang Perlindungan Saksi dan Korban terhadap LPSK, secara umum terkesan sudah mencukupi namun kewenangan dari lembaga ini masih kurang memadai. Ada beberapa ketentuan yang seharusnya ditetapkan dalam UndangUndang PSK ini, salah satunya adalah mengenai masalah pemberian bantuan terhadap saksi dan korban.

Pelaksanaan perlindungan saksi tidak terlepas dengan beberapa persoalan yakni; penegakkan hukum perlindungan saksi,kapan dilakukan perlindungan saksi, bentuk-bentuk perlindungan saksidan tata cara perlindungan saksi dalam proses peradilan pidana.

Salah satu alat bukti yang sah dalam proses peradilanpidana adalah keterangan saksi dan/atau korban yang mendengar,melihat, atau mengalami sendiri terjadinya suatu tindak pidanadalam upaya mencari dan menemukan kejelasan tentang tindakpidana yang dilakukan oleh pelaku tindak pidana; Penegak hukumdalam mencari dan menemukan kejelasan tentang tindak pidanayang dilakukan oleh pelaku tindak pidana sering mengalamikesulitan karena tidak dapat menghadirkan saksi dan/atau korbandisebabkan adanya ancaman, baik fisik maupun psikis dari pihaktertentu. Sehubungan dengan hal tersebut, perlu dilakukanperlindungan bagi saksi dan/atau korban yang sangat pentingkeberadaannya dalam proses peradilan pidana.

Kesaksian memang dibutuhkan dalam setiap pengadilan pidana, termasuk pengadilan militer. Saksi yang dimintaiketerangan dalam penyidikan maupun persidangan, pada dasarnyasangat membantu berjalannya rangkaian proses peradilan. Apalagihasil yang diharapkan dari proses pengumpulan keterangan saksiuntuk memastikan peradilan yang jujur (fair trial).

Dalam penegakan perlindungan saksi khususnyaperlindungan hukum bagi saksi itu sendiri saat ini telah diatur olehUndang-undang Nomor 13 Tahun 2006 tentang Perlindungan Saksidan Korban.Sebuah Undang-undang 
Perlindungan Saksi dan Korbanyang berlaku efektif, yang dibentuk atas dasar upaya tulus untukmengatasi permasalahan seperti pelanggaran hak asasi manusia,adalah satu kesatuan integral dalam rangka menjaga berfungsinyasistem peradilan pidana terpadu.

\section{Undang-undang}

PerlindunganSaksi dan Korban diharapkan akan menolong negara ini keluar dari persoalan-persoalan hukum yang berkepanjangan. Perlindungan terhadap saksi dan korban harus diberikan bila menginginkan proses hukum berjalan benar dan keadilanditegakkan. Hal ini dapat diperhatikan bahwa adanya faktamenunjukkan, banyak kasus-kasus pidana maupun pelanggaranHak Asasi Manusia yang tidak terungkap dan tidak terselesaikandisebabkan adanya ancaman baik fisik atau psikis maupun upaya kriminalisasi terhadap saksi dan korban ataupun keluarganya yangmembuat masyarakat takut memberi kesaksian kepada penegakhukum.

Dalam Pasal 33-Pasal 36 Undang-Undang Perlindungan Saksi dan Korban mengenai tata cara pemberian bantuan, tidak menetapkan mengenai berbagai ketentuan yang seharusnya disepakati oleh LPSK dengan saksi dan/atau korban agar dapat berjalan beriringan. Akan lebih baik jika LPSK beserta saksi dan/atau korban yang akan menerima bantuan tersebut, membuat perjanjian-perjanjian tentang bantuan yang akan dilakukan oleh orang-orang, institusi atau organisasi untuk kepentingan LPSK yang lebih luas.

Selain itu Undang-Undang LPSK ini mempunyai beberapa hal yang merupakan kelemahan, yaitu: Tidak mengatur tentang cara bagaimana penegak hukum memberikan perlindungan terhadap saksi dan korban, bahkan terhadap jaksa dan keluarganya sendiri, mengingat baik saksi maupun korban dan Jaksa dalam kenyataannya kesulitan untuk mengamankan diri dan keluarganya.

Nyoman Serikat Putra Jaya mengemukakan bahwa dalam hukum positif dilndonesia, masalah perlindungan saksi dan korban sudah mendapat pengaturan meskipun sifatnya sangat sederhana dan parsial. Hal ini dapat dilihat dalam hukum pidana materiil maupun hukum pidana formil. Dalam hukum pidanamateriil terlihat dalam Pasal 14 huruf $c$ Kitab Undangundang Hukum Pidana,dalam hal hakim akan menjatuhkan pidana bersyarat, ditentukan adanya syaratumum dan syarat khusus yang harus dipenuhi oleh terpidana selama dalam 
masapercobaan. Syarat khusus berupa terpidana dalam waktu tertentu, yang lebihpendek daripada masa percobaannya, harus mengganti segala atau sebagiankerugian yang ditimbulkan oleh perbuatannya. (Nyoman Serikat Putra Jaya; 2006 : 5).

Hambatan lain yang ada dalam berkembangnya kinerja LPSK ini adalah kurangnya informasi ataupun sosialisasi bagi masyarakat, sehingga minimnya pengetahuan masyarakat akan kehadiran LPSK ini walaupun telah diundangkannya Undang-Undang Perlindungan Saksi dan Korban. Karena itulah pemberian informasi kepada masyarakat luas sangatlah perting diadakan, terlebih khusus untuk memberikan informasi kepada para saksi dan korban akan kehadiran LPSK ini. LPSK pun harus dapat membangun lagi kepercayaan dari masyarakat terhadap kinerjanya dengan terus memperbaiki kelemahan dan kekurangan yang mereka miliki.

Dari berbagai kelemahan dan keterbatasan yang dimiliki oleh LPSK, dapat dilihat bahwa kinerja LPSK dalam hal memberikan perlindungan terhadap saksi dan korban ini tidak bisa berjalan secara efektif tanpa adanya perubahan akan Undang-Undang Perlindungan Saksi dan Korban itu sendiri.

\section{PENUTUP}

Mekanisme

pemberian perlindungan saksi dan korban diatur dalam pasal 29 dan dalam Peraturan LPSK Nomor 6 Tahun 2010 tentang tata cara pemberian perlindungan saksi dan korban. yaitu sebelum LPSK memberikan perlindungannya, saksi dan/atau korban haruslah mengajukan permohonan memenuhi persyaratan yang ditentukan oleh LPSK, yang terkadang dirasakan berat oleh saksi dan korban untuk melakukannya.

Efektifitas Lembaga Perlindungan Saksi dan Korban belum begitu efektif melaksanakan tugas dan wewenangnya hal ini karena terbentur dengan Kelemahan akan Undang-Undang Perlindungan Saksi dan Korban secara langsung menghambat kinerja LPSK.

Hambatan atau kendala-kendala dalam Undang-Undang Nomor 13 Tahun 2006 tentang Perlindungan Saksi dan Korban adalah kurangnya informasi ataupun sosialisasi bagi masyarakat, sehingga minimnya pengetahuan masyarakat akan kehadiran LPSK ini walaupun telah diundangkannya Undang-Undang Perlindungan Saksi dan Korban.

\section{DAFTAR PUSTAKA}

\section{A. Literatur:}

Abdulah, Edi., Muhadar., Thamrin Husni. 2010. Perlindungan Saksi dan 
Korban dalam Sistem Peradilan

Pidana. PNM. Surabaya.

Asshiddiqie, Jimly. 2007.Pokok-pokok

Hukum Tata Negara Indonesia

PascaReformasi. PT Bhuana IImu

Populer. Jakarta.

Arief, Barda Nawawi.1996. Bunga Rampai Kebijakan Hukum Pidana. Citra AdityaBakti. Bandung.

Djamali, Abdoel. 2005. Pengantar Hukum Indonesia edisi revisi. Jakarta. PT. Raja Grafindo Persada.

Djindang, Saleh. 1982. Pengantar Dalam Hukum Indonesia cetakan ke sebelas. Jakarta. Pustaka Sinar Harapan.

Gosita, Arief. 1993. Masalah Korban Kejahatan, Jakarta. Akademika Pressindo.

Marbun, Rocky. 2009. Cerdik dan Taktis Menghadapi Kasus Hukum. Jakarta. Visimedia.

Muladi. 1995. Kapita Selekta Sistem Peradilan Pidana. Semarang. Badan Penerbit Universitas Diponegoro. dan Barda Nawawi Arief. 1992.Bunga Rampai Hukum Pidana, Bandung. Alumni.

Mulyadi, Lilik. 2010. Kompilasi Hukum Pidana dalam Perspektif Teoritis dan Praktik Peradilan. Bandung. Mandar Maju.

Nyoman Serikat Putra Jaya. 2006 Sistem Peradilan Pidana (Criminal Justice system), Bahan Kuliah, Program Megister IImu Hukum Universitas Diponegoro, Semarang.
Projodikoro, Wirjono. 1981. Hukum Acara Pidana di Indonesia, Bandung: Sumur Bandung

Sunarso Siswanto. 2012. Viktimologi dalam Sistem Peradilan Pidana. Sinar Grafika.

Waluyo, Bambang. 2011. Viktimologi Perlindungan Korban dan Saksi. Jakarta. Sinar Grafika.

\section{B. Perundang-Undangan:}

Undang-Undang Nomer 13 Tahun 2006 Tentang Perlindungan Skasi dan Korban.

Undang-Undang Nomer 39 Tahun 1999 Tentang Hak Asasi Manusia.

Undang-Undang RI nomor 31 tahun 1999 sebagaimana diubah dengan Undang-undang RI nomor 20 tahun 2001 tentang perubahan atas Undang-undang RI nomor 31 tahun 1999.

\section{Sumber Website ;}

- https://wonkdermayu.wordpress.com/ kuliah-hukum/delik-delik-khusus/

- http://delik-deliksurya.blogspot.co.id/

- https://wonkdermayu.wordpress.com/ kuliah-hukum/hukum-pidana/

- https://parismanalush2013.wordpres s.com/2015/04/15/actus-reuskejahatan-yang-dilakukan-end-mensrea-sikap-bathin-pelaku-saatmelakukan/

- http://gobloglaw.blogspot.co.id/2012/ 06/actus-non-facit-reum-nisi-menssit-rea.html

- https://wanspeak.wordpress.com/201 0/08/11/319/ 
